\title{
税関別貿易統計を用いた国際海上貨物流動量の推計*
}

\section{Estimation Method for International Seaborne Freight Flows Using Trade Statistics by Customs*}

小坂浩之**

By Hiroyuki KOSAKA**

\section{1. はじめに}

東アジアの経済成長は、国際的な輸送機関の移動を急 激に増加させている。運輸政策の立案者、国際的な物流 業者等は、適切な社会資本整備や物流ネットワークの構 築を行うため、様々な検討を進めている。その際、国際 貨物流動に関する総合的な統計データが必要になる。ア ジア地域においては、現在の所、海上コンテナ輸送量の 包括的なデータベースは構築されていない。データベー スを構築する際に、国際貨物流動量を把握する 1 つの方 法として、貿易統計を利用することが考えられる。本研 究では、貿易統計を用いてコンテナ貨物を推計する手法 において、税関別の貿易統計を使用し、港湾別の国際貨 物流動量を推計することを目的にする。推計の対象は、 日本、韓国、中国であり、3力国の既存統計の特性を把 握し、その統計值と推計結果を比較することで、推計手 法の妥当性を検討する。

\section{2. 日本、中国、韓国の統計の概要}

（1）日中韓の国際海上コンテナ貨物統計の内容 日本、韓国、中国の国際海上コンテナ貨物に関して、 各国政府の主要な統計として、日本では国土交通省1)、 韓国では国土海洋部 2 、中国では交通部 ${ }^{3)}$ の公表物が挙 げられる。

韓国国土海洋部は、Shipping \& Port-Internet Data Center (SP-IDC) という組織を設立し、そこでの統計シス テムで韓国の港湾と外国の港湾間の輸出入コンテナ貨物 量を公表している。統計值は、実入コンテナと空コンテ ナ、自国船と外国船別、直行とトランシップ(以下、 $\mathrm{T} / \mathrm{S}$ と略す)別のコンテナ貨物量がTEU単位で把握可能である。 ヒヤリングによると、韓国港湾の輸出入における相手港 湾は、輸入は原産地国、輸出は最終目的地国である。イ ンターネット上のデータベースでは、2005年に日本、中 *キーワーズ : 空港・港湾計画、物流計画 **正員、博士 (工学) 、( 独) 海上技術安全研究所 - 物流研究 センター

(東京都三鷹市新川6丁目38-1、TEL:0422-41-3699、 E-mai1:hkosaka@nmri.go.jp)
国と輸出入が行われた港湾として、11港湾が存在する。 日本国土交通省は、日本の港湾から相手国別の輸出入ב ンテナ貨物量を公表している。2005年に中国、韓国と輸 出入が行われた港湾として、63港湾が存在する。統計值 は、実入コンテナと空コンテナ、直行とトランシップ別 のコンテナ貨物量がTEU単位で把握可能である。日本港 湾の輸出入における相手国は、仕出国と仕向国であり、 これは、原産地国や最終目的地国の定義と異なる。仕出 国は、日本港湾で船卸したコンテナの最終に船積した国 であり、仕向国は、日本港湾で船積したコンテナの最初 に船卸した国である。中国交通部は、国間または港湾間 の海上コンテナ貨物の統計值は公表していない。

以上の様に、日中韓の政府による統計值において、韓 国と日本間または韓国と中国間では、SP-IDCより港湾間 のコンテナ貨物量が把握可能であるが、日本と中国間で は、港湾間のコンテナ貨物量は把握できない。ただし、 日本と中国間では、船社が報告する内容を取り䌂めて統 計值が公表され、一部の主要な港湾間でのコンテナ貨物 量が把握可能である4)。しかし、そのような船社の輸送 実績は、船社の加入状況の変化による不確実性、継続的 な統計值の公表、統計作成の基準等の点で利用の際に困 難が伴う。

（2）日本と韓国間のコンテナ貨物統計の比較

国土交通省の港湾統計と国土海洋部のSP-IDC統計を使 用して、両統計值の相互比較を行うことで特性を把握す る。表- 1 は、日本と韓国間のコンテナ貨物の流動につ いて、2005年の両統計から得られるTEU単位の統計值を 示している。日本港湾統計のコンテナフローでは、相手 国の定義が仕出国もしくは仕向国であるため、韓国港湾 において事前にT/Sされたコンテナ、もしくは事後にT/S されるコンテナが含まれる。SP-IDC統計のコンテナフロ 一では、相手国の定義が原産地国と最終目的地であるこ とから、日本港湾でのT/Sは行われない。T/Sコンテナは、 統計を作成する国において、T/Sが行われた貨物である。 また、T/Sコンテナにおいて、T/Sが行われる港湾に流入 することをInward T/S、その港湾から流出することを $0 \mathrm{u}$ tward T/Sと記述する。以上の内容から、日本の輸入で は、日本港湾統計のコンテナフローが、SP-IDC統計のコ 
ンテナフローとOutward $\mathrm{T} / \mathrm{S}$ コンテナの合計に定義上一 致する。日本の輸出では、日本港湾統計のコンテナフロ 一は、SP-IDC統計のコンテナフローとInward T/S コンテ ナの合計と定義上一致する。

日本の輸入に着目寸ると、日本港湾統計では、実入コ ンテナフローが84万TEUであり、SP-IDC統計では、実入 コンテナフローの35万TEUと実入outward $\mathrm{T} / \mathrm{S}$ コンテナの 49万TEUの合計が84万TEUであり、日本港湾統計とSP-IDC 統計がよく一致している。この傾向は、日本の輸出と空 コンテナでも存在する。この結果から、SP-IDC統計を利 用することで、日本港湾の韓国を原産地と最終目的地と した輸入と輸出が検討可能と言える。ただし、日本の港 湾ごとに統計值を観察するとT/Sコンテナの記録に疑問 が生じる。日本輸入の実入Inward T/Sは、金沢港、名古 屋港、大阪港、神戸港のみに記録が存在し、その合計で ある約1万TEUの $95 \%$ が金沢港によるものである。他の主 要港において、T/Sコンテナの記録が存在しない場合が あり、T/S コンテナとしての捕捉率が各港湾により異な ると考えられる。この際、T/Sコンテナの記録が久落し ている以上に、T/S コンテナではなくコンテナフローと して記録・報告されている可能性が高いことから、日本 のコンテナフローが大きな值になっていると考えられる。 この特性は、日本のT/Sコンテナが比較的に少ないため、 影響が小さいと考えられる。

表- 1 日韓間の日本港湾統計とSP-IDC統計の比較

\begin{tabular}{|c|c|c|c|}
\hline \multirow{6}{*}{$\begin{array}{l}\text { 日本 } \\
\text { 輸 } \\
\text { 入 }\end{array}$} & 統計項目 & 日本港湾統計 & SP-IDC統計 \\
\hline & 実入コンテナフロー & 842,895 & $\begin{array}{l}353,956 \\
\end{array}$ \\
\hline & 実入 & 10,185 & 488,112 \\
\hline & 実入 阡” & 853,080 & 842,068 \\
\hline & 空コンテナフロー & 147,534 & 104,636 \\
\hline & 空行コシテテ & 62 & 31,931 \\
\hline \multirow{7}{*}{$\begin{array}{l}\text { 日 } \\
\text { 本 } \\
\text { 輸 } \\
\text { 出 }\end{array}$} & 空 計 & 147,596 & $136-567$ \\
\hline & 実入コンテナフロー & 608,916 & 273,683 \\
\hline & 実入厅/Sコシテチ & 4,506 & 337,144 \\
\hline & 箺入 計 & 613,422 & 610,827 \\
\hline & 空コンテナフロー & 494,975 & 482,806 \\
\hline & 空T/Sコシテチ & 0 & 23,686 \\
\hline & 空 & 494,975 & 506,492 \\
\hline
\end{tabular}

（3）日本と中国間のコンテナ貨物統計の比較

ここでは、日本と中国間のコンテナ貨物流動量を比較 する。表-2は、2005年の日本の港湾統計と船社の輸送 実績に基づく統計值を比較したものである。ここでの船 社の輸送実績は、T/Sコンテナや空コンテナの取扱いが 明記されていない。空コンテナについては、日本の港湾 統計によると、日本の輸出で143万TEU存在し、これは船 社の輸送実績である86万TEUを超えるため、船社の輸送 実績に空コンテナが含まれていないと判断した。また、 2002年を対象とした船社の輸送実績の資料5)では、直行
貨物とトランシップ貨物の合計であることが示されてい ることから、2005年の統計值も合計值であるとした。実 入コンテナの合計值では、日本の港湾統計に比心゙、船社 の輸送実績の值は20\%程小さい。これにより、船社の輸 送実績が全体をカバーしていない可能性が推測される。 また、日本の港湾統計は、相手国の定義が仕出国、仕向 国であり、コンテナ貨物の原産地や最終目的地の把握が 直接的には困難である。2003年のデータで詳細に分析し た研究6)から、中国を仕出国もしくは仕向国とした統計 值は、中国を原産国もしくは最終目的国とした統計值に 比へ、5\%程度大きくなると考えられる。また、2002年の 船社の輸送実績) においては、T/S コンテナの大きさは コンテナフローに対して5\%程度である。よって、日本と 中国間のコンテナ貨物量に関しては、仕出国と原産地国、 仕向国と最終目的国の相違と、T/S コンテナの存在によ るコンテナフローに対する影響は小さいと考えられる。

\begin{tabular}{|c|c|c|c|}
\hline 表- 2 & $\begin{array}{l}\text { 統計項目 } \\
\end{array}$ & 日本港湾統計 & 船社輸送実績 \\
\hline \multirow{6}{*}{$\begin{array}{c}\text { 日 } \\
\text { 本 } \\
\text { 輸 } \\
\text { 入 }\end{array}$} & 実入コンテナフロー & $2,361,011$ & 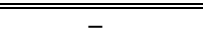 \\
\hline & 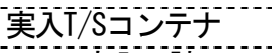 & 10,057 & $\cdots$ \\
\hline & 実入 訐 & $2,371,068$ & $2,006,606$ \\
\hline & 空コンテナフロー & 52,947 & - \\
\hline & 空行コシテテ & 1 & $\overline{-}$ \\
\hline & 空 阡 & 52,948 & - \\
\hline \multirow{6}{*}{$\begin{array}{l}\text { 日 } \\
\text { 本 } \\
\text { 輸 } \\
\text { 出 }\end{array}$} & 実入コンテナフロー & $1,115,981$ & - \\
\hline & 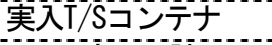 & 7 & - \\
\hline & 実入 & $1,115,988$ & 860,280 \\
\hline & 空コンテナフロー & $1,428,838$ & - \\
\hline & 空门/Sコシテテ & 1 & - \\
\hline & 空 許 & $1,428,839$ & - \\
\hline
\end{tabular}

\section{3. 国際貨物流動量の推計手法と使用データ}

(1) 推計手法

アジア地域のコンテナ貨物の統計利用が困難であるこ とから、各種の推計手法が提案されている7等。筆者ら は、国際的な作成方法の標準化が進められている貿易統 計を使用することで、統一的な基準に従った国際貨物流 動量の推計手法の確立を進めている8 ${ }^{8}$ 。推計手法の概要 を図- 1 に示す。筆者らの従来の推計手法は、国間の貨 物流動量を推計するのみであった。本研究では、港湾別 の貨物流動量を推計可能な手法に発展させるため、利用 可能なデータの検討や試験的な推計を行う。

具体的には、上記の推計手法に基づき、新たなデータ として日本と中国の税関別貿易統計データを使用し、港 湾別の国際貨物流動量の推計を試みる。この推計フロー の第1段階では、基礎データとなる貿易統計に存在する 不整合問題を検討する。不整合問題は、ある国の輸出 (輸入) と対応する輸入（輸出）に関して、金額もしく 


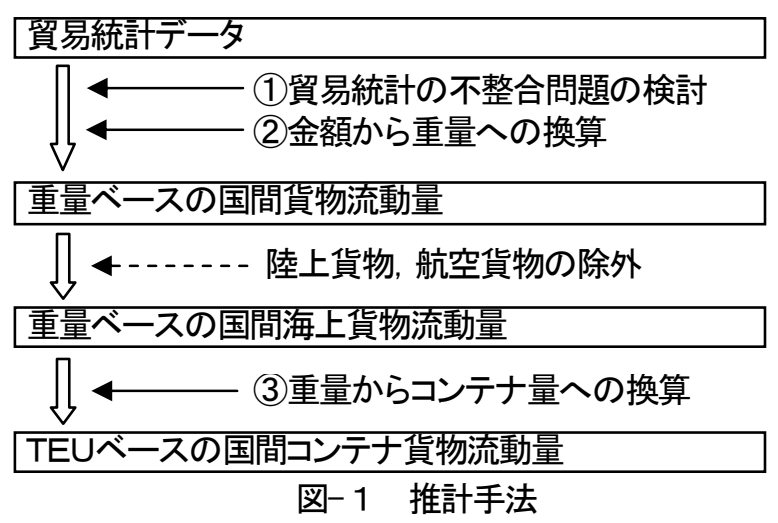

は数量の值が大きく靟離することである。本研究では、 使用する貿易統計データの不整合問題の状況を示す。

推計フローの第2段階では、貿易統計の金額ベースの 貨物量を重量ベースに統一寸る。一般的な貿易統計デー 夕は、品目によって重量以外の数量単位が存在する。そ のような品目の重量べースの貿易量を推計するために、 金額重量間換算係数 (Metric Ton/1000USドル)を使用す る。税関 $(\mathrm{cu})$ の輸入 (M) に関する品目 (i) 別、相手国 (pa) 別の金額重量換算係数 $F_{M, i}^{c u, p a}$ と、同様の輸出 $(X)$ に関 する金額重量換算係数 $F_{X, i}^{c u, p a}$ は、式(1) と式(2)で示さ れる。

$$
\begin{aligned}
& F_{M, i}^{c u, p a}=\frac{W_{M, i}^{c u, p a}}{V W_{M, i}^{c u, p a}} \\
& F_{X, i}^{c u, p a}=\frac{W_{X, i}^{c u, p a}}{V W_{X, i}^{c u, p a}}
\end{aligned}
$$

ここで、

$V W_{M, i}^{c u, p a}:$ 税関 $c u$ の相手国 pa からの品目 $\mathrm{i}$ の輸入 $\mathrm{M}$ に関して、重量データが存在する貿易データ の輸入額

$W_{M, i}^{c u, p a}: V W_{M, i}^{c u, p a}$ に対応する輸入重量

$V W_{X, i}^{c u, p a}:$ 税関 $c u$ の相手国 pa に対する品目 $\mathrm{i}$ の輸出 $\mathrm{X}$ に関して、重量データが存在する貿易データ の輸出額

$W_{X, i}^{c u, p a}: V W_{X, i}^{c u, p a}$ に対応する輸出重量

である。金額重量間換算係数は、HS類品目（約100品目、 2栴コード）とHS項品目（約1000品目、4栴コード）別に 集計して算出する。詳細であるHS項品目の金額重量間換 算係数を優先し、重量が存在しないHS号品目（約5000品 目、6桁コード）の貿易額に掛け合わせることで、金額 から重量への換算を行う。また、一般的な貿易統計デー 夕を使用した場合、重量べースの貨物量には、陸上輸送 や航空輸送の貨物量が含まれている。本研究では、港湾 と空港に対応寸る税関別貿易統計と、税関別輸送機関別 貿易統計を使用することで、陸上輸送や航空輸送の貨物 量を除外している。
推計フローの第3段階では、HS号品目別の重量ベース の貨物量に、海上コンテナ化率、重量TEU間換算係数(TE U/Metric Ton)を掛け合わせることで、TEUベースの国際 海上コンテナ量を推計する。海上コンテナ化率は、日本 の財務省が公表する海上コンテナ分の貿易統計 を利用 して算出している。これは、全輸送機関分の貿易額に対 する海上コンテナ分の貿易額の比率であり、HS号品目別 に作成している。重量TEU間換算係数は、米国のPort Im port Export Reporting Service (PIERS)のデータベー スから、Metric TonとTEUが明記されたデータを抽出し、 HS号品目別に換算係数を作成している。PIERSのデータ ベースは、米国とアジア諸国間の貿易を対象にしたもの を利用している。

本研究では、筆者らの過去の研究8) と同様に、上記の 推計フローを用いている。筆者らの過去の研究8) で使用 した一般的な貿易統計データは、国単位に集計し公表さ れているが、税関別貿易統計データでは、輸出入の申告 が行われた税関別に貿易統計が公表されている。本研究 では、税関と港湾の対応関係を設定し、税関別貿易統計 データから港湾別の貨物流動量を推計する。また、税関 別貿易統計としては、Global Trade Information Servi ce社 (GTIS社) が販売しているWorld Trade Atlasデー 夕(WTAデータ)を使用する。GTIS社は、各国の貿易額が 自国通貨である場合には、USドルへの変換を行っている が、数量に関するデータは、基本的に各国の貿易関連機 関が公表するデータと一致している。また、国連やOECD が公表寸るデータと基本的には大きな相違はない。

（2）使用データ

a）日本の税関別貿易統計の内容

WTAデータおける日本の税関別貿易統計についての概 要を表- 3 に示す。貿易統計の区分における税関は 152 税 関存在し、123税関が港湾を管轄し24税関が空港を管轄 している。残りの5税関は、札幌税関支署、鹿島税関支 署つくば出張所、横浜税関宇都宮出張所、京都税関支署、 京都税関支署滋賀出張所であり、港湾や空港の所在と対 応していない。これらの税関のデータは、税関で実施さ れている輸出入貨物の物流動向調査の国内貨物流動結果 を参考にし、港湾に対応させる。WTAデータの日本税関 別貿易統計では、輸送機関別のデータが存在しないが、

表-3 日本の税関別貿易統計 (WTAデータ) の概要

\begin{tabular}{l|l}
\hline \multicolumn{1}{c|}{ 項目 } & \multicolumn{1}{c}{ 摘要 } \\
\hline \hline 対象年 & 1994 年以降 \\
\hline 税関 & 152 税関（港湾） \\
\hline
\end{tabular}

輸送機関 輸送機関合計

相手国数 輸入 229 輸出 230 輸出入 231

品目数 HS9 桁品目 (輸入 10621 品目 輸出 7734 品目) 数量単位 15 種類 重量 (Ton, $\mathrm{Kg}$, 等)、個数、容積、等 
税関が港湾や空港と対応しているため、港湾別、空港別 の国際貨物流動量が可能と考えられる。品目分類はHSで あり、基本的に国際的に標準的な分類に従っている。日 本の貿易統計は、HS号品目（6桁コード）をさらに細分 化した9枌の数字で示されるコードで記録されている。9 桁コードの品目をHS号品目に集計する際に、一部の品目 は国際標準と一致しない。独自品目は、9栴のコードで6 品目が存在した。本報告では標準的なHS号品目分類に、 その独自品目を新たな品目として加えて、処理を行って いる。また、数量単位は15種類存在し、これを国連の数 量単位に従うように変換した。この際、Gross Tonは国 連の数量単位に存在しないため、新たな数量単位として 加えている。

b）中国の税関別貿易統計の内容

WTAデータにおける中国税関別貿易統計について、そ の概要を表-4に示す。WTAデータでは、別途、香港、マ カオ、台湾の貿易統計が存在し、本研究では中国本土の 貿易統計を使用する。税関は41税関存在し、これは中国 の省・市・特別区に対応しており、広東省の珠江デルタ 地域に関しては、広州(Guangzhou)、江門(Jiangmen)、 拱北 (Gongbei)、黄埔(Huangpu)、深セン(Shenzhen) が存 在する。中国の税関別貿易統計では、日本の税関別統計 に比へ、税関の管轄が港湾や空港の管轄と直接的に対応 していない。また、海上輸送、航空輸送、陸上輸送、そ の他輸送別にデータが整備されているため、海上輸送分 の貨物の抽出が可能である。品目分類は、HSの8桁品目 であり、本研究では、これをHS号品目で集計して取り扱 う。また、数量単位は 13 種類存在し、これを国連の数量 単位に従うように変換している。

表-4 中国の税関別貿易統計 (WTAデータ) の概要

\begin{tabular}{l|l}
\hline \multicolumn{1}{c|}{ 項目 } & \multicolumn{1}{c}{ 摘要 } \\
\hline 対象年 & 1995 年以降 \\
\hline 税関 & 41 税関 $($ 省・市・自治区等 $)$ \\
\hline
\end{tabular}

輸送機関輸送機関合計、海上、航空、陸上、その他

相手国数輸入 232 輸出 236 輸出入 238

品目数 HS8 桁品目 (輸入 8695 品目 輸出 8666 品目) 数量単位 13 種類 重量 (Ton, $\mathrm{Kg}$, 等)、個数、容積、等

\section{（3）貿易統計データの整合性}

本研究の基礎データである貿易統計データに関して、 整合性の確認を行う。整合性は、日本、中国、韓国間の 輸入額と対応する輸出額から整合率（輸入額／輸入額に 対応する輸出額) を算出して行う。

日本と韓国間のWTAデータに関して、貿易統計の整合 性を表- 5 に示す。表- 5 では、日本の輸出入の相手国を 韓国とした場合の貿易額と、韓国の輸出入の相手国を日 本とした場合の貿易額を使用して、日本と韓国間の貿易 額の整合率を算出している。輸入額は、運賃と保険料を
表- 5 日本と韓国間の貿易額の整合性

\begin{tabular}{c|c|c|c}
\hline データ & 2003 年 & 2004 年 & 2005 年 \\
\hline \hline 日本の対韓国輸入額 & 17,929 & 22,065 & 24,424 \\
\hline 韓国の対日本輸出額 & 17,276 & 21,701 & 24,027 \\
\hline 整合率 & 1.04 & 1.02 & 1.02 \\
\hline \hline 韓国の対日本輸入額 & 36,313 & 46,144 & 48,403 \\
\hline 日本の対韓国輸出額 & 34,828 & 44,282 & 46,627 \\
\hline 整合率 & 1.04 & 1.04 & 1.04 \\
\hline \multicolumn{4}{|c}{ 貿易額: 100 万USドル }
\end{tabular}

含むCIF価格であり、輸出額はそれを含まないFOB価格で あり、整合率は1.0より大きくなる。一般に、整合性に 問題がない場合、各国の輸入総額や輸出総額の整合率は 1.1程度になり、国間ごとの整合率は1.1から多少ばらつ く程度である。本報告で使用寸るWTAデータにおける日 本と韓国間の貿易額は、整合率の観点では大きな問題が ないことがわかる。

次に、表-6は、中国の輸出入の相手国を日本とした 場合の貿易額と、日本の輸出入の相手国を中国とした場 合の貿易額を使用して、中国と日本間の貿易額の整合率 を算出した結果である。中国輸入日本輸出、日本輸入中 国輸出共に整合率が1. 3程度であり、標淮的な值である1. 1より若干大きい。この原因として、香港の再輸出活動 が考えられる(注。この点に関しては、香港の再輸出に 関する貿易統計を利用して検討する必要があるが、本研 究ではコンテナ貨物の試験的な推計を目的としているた め、特に修正を行っていない。

表-6 中国と日本間の貿易統計の整合性

\begin{tabular}{|c|c|c|c|}
\hline データ & 2003 年 & 2004 年 & 2005 年 \\
\hline 日本の対中国輸入額 & 75,678 & 94,470 & 108,526 \\
\hline 中国の対日本輸出額 & 59,454 & 73,536 & 84,097 \\
\hline $\begin{array}{c}\text { 整合率 } \\
\end{array}$ & 1.27 & 1.28 & 1.29 \\
\hline 中国の対日本輸入額 & 72,204 & 94,192 & 100,468 \\
\hline 日本の対中国輸出額 & 57,474 & 73,972 & 79,972 \\
\hline 整合率 & 1.26 & 1.27 & 1.26 \\
\hline
\end{tabular}

次に、表- 7 は、中国の輸出入の相手国を韓国とした 場合の貿易額と、韓国の輸出入の相手国を中国とした場 合の貿易額を使用して、中国と韓国間の貿易額の整合率 を算出している。中国輸入韓国輸出において香港の再輸 出活動の影響が見られるが(注)、使用するWTAデータにお ける中国と韓国間の貿易額は、整合率の観点では大きな 問題がないことがわかる。 
表-7 中国と韓国間の貿易統計の整合性

\begin{tabular}{c|c|c|c}
\hline データ & 2003 年 & 2004 年 & 2005 年 \\
\hline \hline 中国の対韓国輸入額 & 43,161 & 62,165 & 76,874 \\
\hline 韓国の対中国輸出額 & 35,110 & 49,763 & 61,915 \\
\hline 整合率 & 1.23 & 1.25 & 1.24 \\
\hline \hline 韓国の対中国輸入額 & 21,909 & 29,585 & 38,648 \\
\hline 中国の対韓国輸出額 & 20,105 & 27,809 & 35,117 \\
\hline 整合率 & 1.09 & 1.06 & 1.10 \\
\hline \multicolumn{4}{|c}{ 貿易額 : 100 万USドル }
\end{tabular}

\section{4. 国際貨物流動量の推計方法の適用}

（1）日本港湾の対韓国輸出入一の適用結果

推計手法に基づき、日本と韓国間のコンテナ貨物流動 量を推計した結果について、妥当性の検討を行う。貿易 統計は、原則として、相手国の定義が原産地国と最終目 的地国であり、またT/S貨物と空コンテナを対象として いない。本手法の推計結果は、貿易統計の定義に依存す るため、コンテナ貨物の既存統計として、相手国が原産 地国と最終目的地国であり、T/Sコンテナと輸出入貨物 が明確に分離されている国土海洋部のSP-IDC統計と、推 計結果の比較を行う。表-8は、2003年、2004年、2005 年の港湾を合計した日本全国に関して、対韓国輸入コン テナ量のSP-IDC統計值と推計值、対韓国輸出コンテナ量 のSP-IDC統計值と推計值を示している。表-8の乘離と は、乘離率（(推計值-統計值)/統計值）を省略して示し ている。2005年については、輸出入合計 (統計值) の上 位5港湾について、統計值と推計值を示している。2005 年の日本の輸入では、SP-IDC統計值が35万TEU、推計結 果が37万TEUであり、推計結果が5\%程度大きい。2005年 の日本の輸出では、SP-IDC統計值が27万TEU、推計結果 が25万TEUであり、推計結果が8\%程度小さい。筆者らが 東アジア10力国間程度を対象にして行った過去の推計手 法の適用結果6) では、既存統計と比べ土10\%程度の推計 精度であり、本研究の推計結果においても同程度の推計 精度である。

\section{表-8 日韓コンテナ貨物量の統計值と推計値の比較}

\begin{tabular}{|c|c|c|c|c|c|c|}
\hline \multirow[b]{2}{*}{ 年 } & \multicolumn{3}{|c|}{ 日本の輸入（対韓国） } & \multicolumn{3}{|c|}{ 日本の輸出（対韓国） } \\
\hline & $\begin{array}{l}\text { SP-IDC } \\
\text { 統計值 }\end{array}$ & 推計値 & 乘離 & $\begin{array}{l}\text { SP-IDC } \\
\text { 統計值 }\end{array}$ & 推計値 & 乘離 \\
\hline 2003 計 & 334 & 340 & $2 \%$ & 240 & 216 & $-10 \%$ \\
\hline 2004 計 & 354 & 368 & $4 \%$ & 260 & 242 & $-7 \%$ \\
\hline 2005 計 & 354 & 372 & $5 \%$ & 274 & 252 & $-8 \%$ \\
\hline 東京 & 69 & 80 & $16 \%$ & 31 & 29 & $-8 \%$ \\
\hline 大阪 & 50 & 51 & $1 \%$ & 37 & 26 & $-27 \%$ \\
\hline 横浜 & 33 & 31 & $-4 \%$ & 43 & 31 & $-29 \%$ \\
\hline 名古屋 & 36 & 40 & $10 \%$ & 30 & 24 & $-18 \%$ \\
\hline 神戸 & 21 & 22 & $2 \%$ & 29 & 29 & $1 \%$ \\
\hline
\end{tabular}

単位 : 1000TEU
次に、日本の港湾別コンテナ貨物推計結果について妥 当性の検討を行う。図-2 は、日本の港湾別の対韓国輸 入コンテナ量と対韓国輸出コンテナ量について、2005年 のSP-IDCの統計值と推計結果の比較を行っている。図2 は、統計值と推計值が一致する場合の 45 度線、統計值 （x）と推計值 $(\mathrm{y})$ の切片を0とした回帰式、その $\mathrm{R}^{2}$ 值を示 している。回帰式の係数とR值から判断して、輸入、輸 出コンテナ共に、全体としてはSP-IDCの統計值と大きな 相違がないことがわかる。

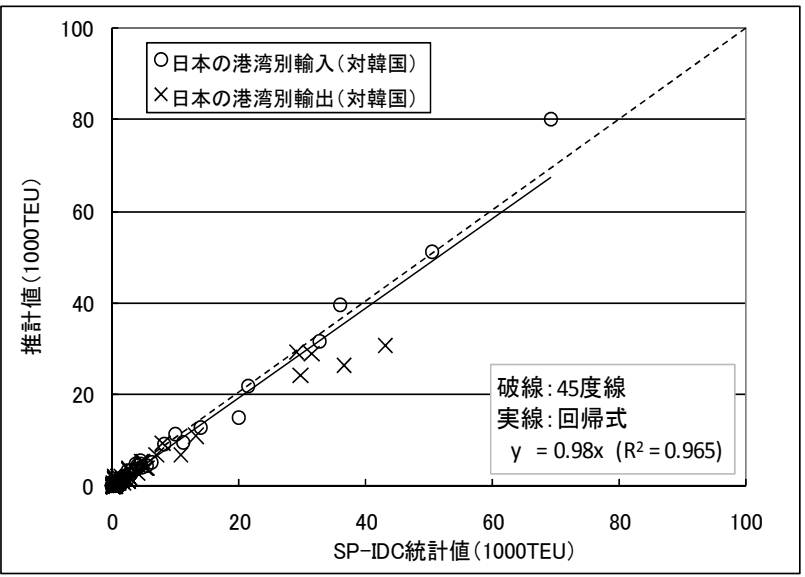

図-2 日本港湾輸出入（対韓国）の推計結果の妥当性

（2）日本港湾の対中国輸出入一の適用結果

推計手法に基づき、日本と中国間のコンテナ貨物流動 量を推計した結果の妥当性を検討する。コンテナ貨物の 既存統計として、T/S貨物の值を除いた日本の港湾統計 を使用する。日本の港湾統計の相手国が、仕出国と仕向 国である点は、相手国が中国である場合は、前述したよ うに、5\%程度の小さな影響と考えられる。表-9 は、200 3年、2004年、2005年の港湾を合計した日本全国に関し て、対中国輸入コンテナ量の港湾統計の值と推計值、対 中国輸出コンテナ量の港湾統計の值と推計值を示してい る。2005年については、輸出入合計（統計值）の上位5 港湾について、統計值と推計值を示している。2005年の 日本の輸入では、港湾統計の值が236万TEU、推計結果が 228万TEUであり、推計結果が4\%程度小さい。2005年の日

表-9 日中コンテナ貨物量の統計値と推計値の比較

\begin{tabular}{|c|c|c|c|c|c|c|}
\hline \multirow[b]{2}{*}{ 年 } & \multicolumn{3}{|c|}{ 日本の輸入（対中国） } & \multicolumn{3}{|c|}{ 日本の輸出（対中国） } \\
\hline & $\begin{array}{l}\text { 港湾本統計 } \\
\end{array}$ & 推計值 & 乘離 & $\begin{array}{l}\text { 港湾本統計 } \\
\end{array}$ & 推計值 & 乘離 \\
\hline 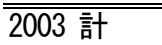 & 1,853 & \begin{tabular}{c|}
1,820 \\
\end{tabular} & $-2 \%$ & 804 & $\mid 959$ & $19 \%$ \\
\hline 2004 計 & 2,214 & 2,239 & $1 \%$ & 984 & 1,076 & $9 \%$ \\
\hline 2005 計 & 2,361 & 2,282 & $-3 \%$ & 1,116 & 1,125 & $1 \%$ \\
\hline 東京 & 535 & 469 & $-12 \%$ & 256 & 185 & $-28 \%$ \\
\hline 横浜 & 362 & 256 & $-29 \%$ & 219 & 135 & $-38 \%$ \\
\hline 大阪 & 483 & 442 & $-8 \%$ & 95 & 84 & $-12 \%$ \\
\hline 名古屋 & 344 & 321 & $-7 \%$ & 162 & 113 & $-30 \%$ \\
\hline 神戸 & 224 & 164 & $-27 \%$ & 171 & 156 & $-9 \%$ \\
\hline
\end{tabular}

単位 : 1000TEU 
本の輸出では、港湾統計の值が112万TEU、推計結果が11 3万TEUであり、推計結果が1\%程度大きい。全体としては、 既存統計と比べ士 $10 \%$ 程度の相違での推計が可能と言え る。

次に、日本の港湾別コンテナ貨物推計結果について妥 当性の検討を行う。図-3は、日本の港湾別の対中国輸 入コンテナ量と対中国輸出コンテナ量について、2005年 の港湾統計の值と推計結果の比較を行っている。回帰式 の係数から判断して、16\%程度、推計值が小さくなる傾 向が存在するが、輸入、輸出コンテナ共に、全体として は港湾統計の值と大きな相違がないことがわかる。

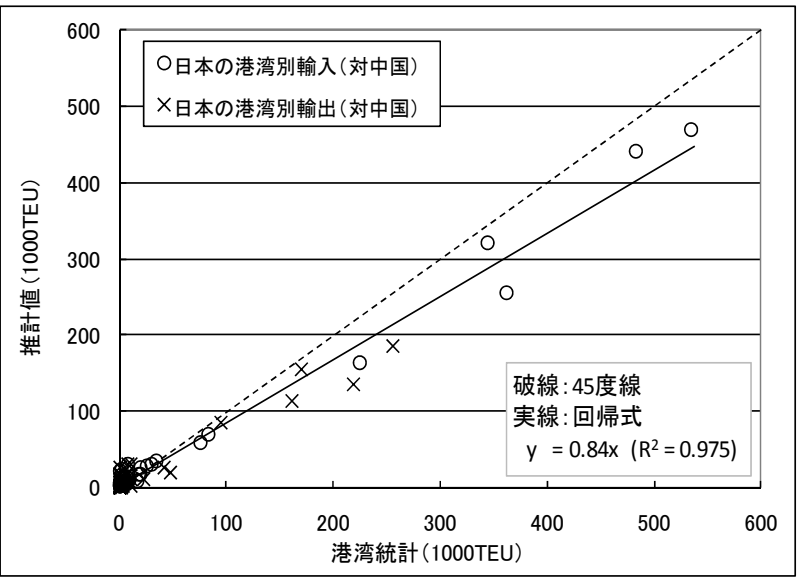

図-3 日本港湾輸出入（対中国）の推計結果の妥当性

（3）中国港湾の対日本輸出入一の適用結果

推計手法に基づき、中国と日本間のコンテナ貨物流動 量を推計した結果について、妥当性の検討を行う。中国 と日本間のコンテナ貨物流動に関しては、日本の港湾統 計では把握できない中国港湾別コンテナ輸出入が、船社 の輸送実績りにより公表されているため、この実績值を 利用して、推計結果との比較を行う。表-10 は、2003 年、2004年、2005年に関して、中国本土の日本からの輸 入と、中国本土の日本への輸出コンテナ量に関して、船 社輸送実績と推計值の比較結果を示している。2005年に ついては、輸出入合計（統計值）の上位5港湾について、 統計值と推計值を示している。2005年では、船社輸送実 績值において、中国輸入76万TEU、中国輸出177万TEUで あり、推計值においては中国輸入118万TEU、中国輸出19 7万TEUである。中国輸入に関しては、過大推計と考えら れる。この原因としては、推計值の全体的な傾向である ため、推計フローの第2段階で使用寸る金額重量間換算 係数において重量データの異常值が存在し、適切な換算 係数が設定されていない可能性、また、推計フローの第 3段階の海上コンテナ化率、重量TEU間換算係数が中国輸 入に対して適合していない可能性がある。中国輸出に関 しては、推計值は10\%程度の乘離である。
表-10 日中コンテナ貨物量の統計値と推計値の比較

\begin{tabular}{|c|c|c|c|c|c|c|}
\hline \multirow[b]{2}{*}{ 年 } & \multicolumn{3}{|c|}{ 中国の輸入（対日本） } & \multicolumn{3}{|c|}{ 中国の輸出（対日本） } \\
\hline & $\begin{array}{l}\text { 定航会 } \\
\text { 統計値 }\end{array}$ & 推計值 & 乘離 & $\begin{array}{l}\text { 定航会 } \\
\text { 統計値 }\end{array}$ & 推計值 & 乘離 \\
\hline 2003 計 & $\begin{array}{ll}669 \\
\end{array}$ & 1,023 & $53 \%$ & 1,583 & 1,722 & $9 \%$ \\
\hline 2004 計 & 778 & 1,233 & $58 \%$ & 1,827 & 1,808 & $-1 \%$ \\
\hline 2005 計 & 860 & 1,176 & $37 \%$ & 2,007 & 1,965 & $-2 \%$ \\
\hline 上海 & 386 & 313 & $-19 \%$ & 822 & 472 & $-43 \%$ \\
\hline 青島 & 60 & 70 & $18 \%$ & 253 & 268 & $6 \%$ \\
\hline 天津 & 123 & 90 & $-27 \%$ & 162 & 156 & $-4 \%$ \\
\hline 大連 & 65 & 48 & $-26 \%$ & 173 & 324 & $88 \%$ \\
\hline 厦門 & 24 & 29 & $18 \%$ & 122 & 185 & $52 \%$ \\
\hline
\end{tabular}

単位 : 1000TEU

次に、中国の港湾別コンテナ貨物推計結果について妥 当性の検討を行う。図一 4 は、中国の港湾別の対日本輸 入と対日本輸出のコンテナ量について、2005年の船社輸 送実績值と推計結果の比較を行っている。2005年の日中 定航会の統計值では12港湾の統計值が示されているが、 この内、上海(Shanghai)、大連(Dalian)、青島(Qingda o)、天津(Tianjin)、厦門(Xiamen)、寧波(Ningbo)、福 州 (Fuzhou)、広州 (Guangzhou) の統計值と比較を行った。 全体としては、船社輸送実績值の傾向を推計值によって 捉えることが可能と考えるが、 $\mathrm{R}^{2}$ 值が日本の税関別貿易 統計を使用した推計結果に比べ小さく、統計值と推計值 間の乘離のばらつきが大きいため、推計精度は十分とは 言えない。特に、中国の対日本輸出コンテナ量において、 統計值が最大である上海の輸出コンテナ量に対して推計 值が過小と考えられる。この原因は、中国の対日本輸出 合計において、統計值と推計值に大きな乘離がないこと から、推計における税関と港湾の対応が不適切であるこ とが考えられる。つまり、上海港のコンテナ貨物に関し ては、上海税関での通関以外に、他税関で通関されるコ ンテナ貨物が多く存在する可能性がある。この点は、中 国の税関別貿易統計のみでは、実態を把握できない。

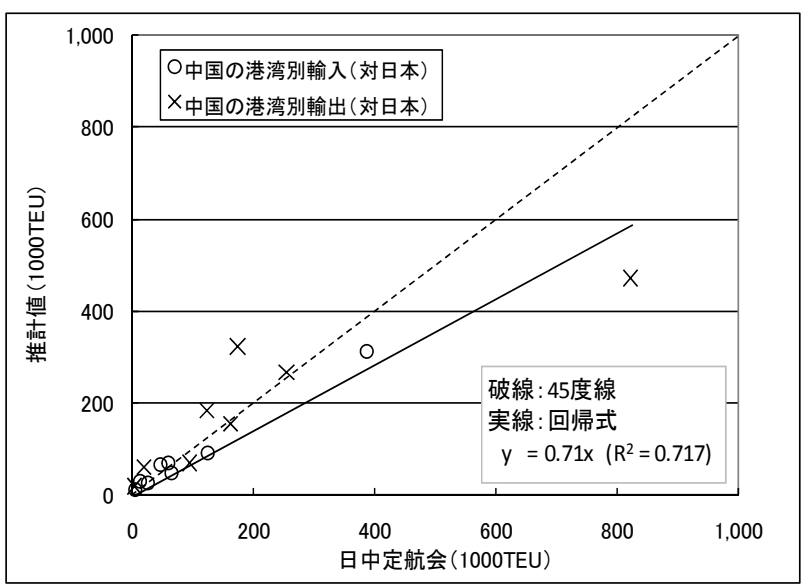

図-4 中国港湾輸出入（対日本）の推計結果の妥当性

（4）中国港湾の対日本輸出入への適用結果

推計手法に基づき、中国と韓国間のコンテナ貨物流動 量を推計した結果について、妥当性の検討を行う。中国 
と韓国間のコンテナ貨物流動に関しては、韓国のSP-IDC の統計值が公表されているため、この統計值と推計結果 の比較を行う。本研究では、中国と韓国間のSP-IDCの統 計值に関して詳細な検討を行っていないため、推計結果 の妥当性に関する概要を把握するの久を目的としている。 表-1 1は、2003年、2004年、2005年に関して、中国本 土の韓国からの輸入と、中国本土の韓国への輸出コンテ ナ量に関して、SP-IDCの統計值と推計值の比較結果を示 している。2005年については、輸出入合計（統計値）の 上位5港湾について、統計值と推計值を示している。200 5年では、統計値において、中国輸入97万TEU、中国輸出 99万TEUであり、推計値においては中国輸入 121 万TEU、 中国輸出 118 万TEUである。輸出入共に $20 \%$ 程度の過大推 計と考えられる。この原因は、中国の輸入 (対日本) と 同様に、金額重量間換算係数、海上コンテナ化率、重量 TEU間換算係数が適合していない可能性が考えられる。

表-11 中韓コンテナ貨物量の統計值と推計値の比較

\begin{tabular}{|c|c|c|c|c|c|c|}
\hline \multirow[b]{2}{*}{ 年 } & \multicolumn{3}{|c|}{ 中国の輸入（対韓国） } & \multicolumn{3}{|c|}{ 中国の輸出（対韓国） } \\
\hline & $\begin{array}{l}\text { SP-IDC } \\
\text { 統計值 }\end{array}$ & 推計值 & 乘離 & $\begin{array}{l}\text { SP-IDC } \\
\text { 統計值 }\end{array}$ & 推計值 & 乘離 \\
\hline 2003 計 & 774 & 990 & $28 \%$ & 693 & 975 & $41 \%$ \\
\hline 2004 計 & 909 & 1,164 & $28 \%$ & 835 & 1,143 & $37 \%$ \\
\hline 2005 計 & 970 & 1,207 & $24 \%$ & 991 & 1,178 & $19 \%$ \\
\hline 青島 & 243 & 190 & $-22 \%$ & 193 & 305 & $59 \%$ \\
\hline 天津 & 264 & 139 & $-47 \%$ & 136 & 153 & $12 \%$ \\
\hline 上海 & 177 & 212 & $20 \%$ & 185 & 165 & $-11 \%$ \\
\hline 大連 & 170 & 59 & $-65 \%$ & 66 & 111 & $69 \%$ \\
\hline 寧波 & 78 & 88 & $13 \%$ & 39 & 39 & $-1 \%$ \\
\hline
\end{tabular}

単位 : 1000TEU

次に、中国の港湾別コンテナ貨物推計結果について妥 当性の検討を行う。図- 5 は、中国の港湾別の対韓国輸 入と対韓国輸出のコンテナ量について、2005年のSP-IDC の統計值と推計結果の比較を行っている。R $\mathrm{R}^{2}$ 值が比較的 小さく、統計值と推計值間の乘離のばらつきが大きいこ とから、全体として、推計精度は十分とは言えない。今 後、詳細な各種換算係数の検討を行うと共に、SP-IDC

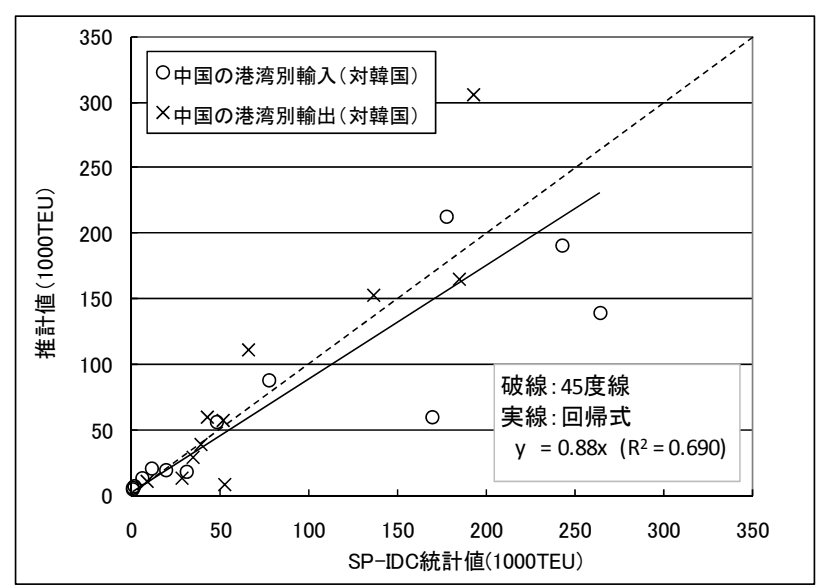

図-5 中国港湾輸出入 (対韓国) の推計結果の妥当性
の統計値の特性分析や、各種既存統計の収集・検討によ る中国の税関と港湾の対応関係の把握を進める必要があ る。

（5）港湾別輸出入コンテナの推計值精度

本研究おいて、相手国を中国、韓国とした日本の港湾 別コンテナ貨物量と、相手国を日本、韓国とした中国の 港湾別コンテナ貨物量の推計を実施した。この推計結果 の全体的な推計精度を検討し、推計手法の適用可能性を 考察する。図-6 は、統計值と推計值加乘離率（(推計 值-統計(值)/統計值）を算出し、統計値の大きさで整理 したものである。統計值が1000TEU以上であるものを対 象とした。統計值が、20万TEU以上の港湾・国間では、 推計值が小さくなる傾向が存在するが、各種係数を再検 討することで、一定規模以上の港湾別コンテナ貨物量は、 推計可能と考えられる。統計值が小さい港湾・国間では、 乘離率が大きく、統計值と推計值の傾向が異なる。

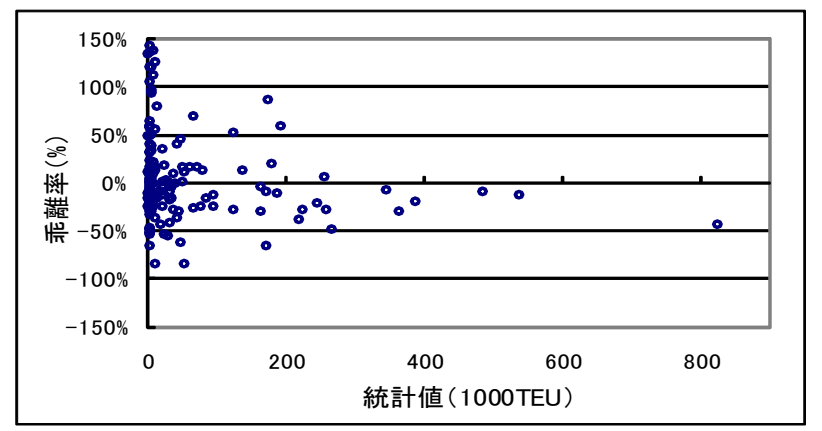

図-6 統計値と推計值の乘離率

\section{5. おわりに}

本研究は、税関別貿易統計を利用し、港湾別の輸出入 コンテナ貨物量を推計する方法を示した。既存統計の特 性を考慮し、統計值と推計值を比較することで、推計結 果の妥当性を検討した。港湾別の推計值では、日本と韓 国間では十分な推計精度と言えるが、日本と中国間、中 国と韓国間では、一部推計精度に問題が生じる。また、 コンテナ貨物量が小規模な港湾では、十分な結果ではな い。今後、更なる既存統計の特性と中国の税関・港湾間 の対応関係の把握、推計に使用する換算係数を修正する ことで、推計精度の向上を進める予定である。

注

香港の再輸出活動によって、整合率の值が大きくなる 原因として、以下が考えられる。輸出国は、最終消費国 を認識せず、貿易統計の記録上、相手国を香港とする (実際は、香港の再輸出が介在し、香港と異なる国が最 終消費国となる）。一方、最終消費国である輸入国は、 香港と異なる国を正確に原産地国として記録する。この 
場合の整合率は、輸入額が正確であり、輸出額が過少に なるため、整合率は大きくなる。香港の貿易統計 ${ }^{10)}$ によ ると、2005年において、香港の再輸出を伴う中国の対日 本輸出額、日本の対中国輸出額、韓国の対中国輸出額、 中国の対韓国輸出額は、それぞれ131億USドル、199億US ドル、79億USドル、33億USドルである。香港の再輸出を 伴う中国の対韓国輸出額は、相対的に小さい。このため、 韓国輸入中国輸出の整合率は、香港の再輸出活動の影響 が少なく、整合率が1.1程度になると考えられる。

\section{参考文献}

1）国土交通省 : 港湾調查, http://toukei. mlit. go. jp /kowan/kowan. html

2) Shipping \& Port-Internet Data Center : 統計情報, http://www. spidc. go. kr/jsp/spidc. jsp

3 ）中国港口編集部：中国港口年鑑2006, 2007.

4) (株オーシャンコマース : 国際輸送ハンドブック 2007 年版, 2007.
5 ）在中国日本商工会議所 : 中国経済・産業の回顧と展 望2002/2003，2003

6 ）赤倉康寛、渡部富博 : 国際海上コンテナ貨物の輸送 経路分析に港湾統計データの考察、国土技術政策総 合研究所資料No. $408 ， 2007$

7 ）柴崎隆一、渡部富博、角野隆、神波泰夫 : アジア圏 を中心とした国際海上コンテナの0D貨物量推計に関 する研究、国土技術政策総合研究所研究報告 No. 25 , 2005.

8）小坂浩之、鹿島茂 : 国際コンテナ貨物量推計手法の 精度改善に関する研究，土木計画学研究・論文集， Vol.21, pp627-632, 2004.

9）財務省 : 財務省貿易統計一海上コンテナ貨物品別国 別表, http://www. customs. go. jp/toukei/info/tsdl. htm

$10)$ Census \& Statistics Dept., Hong Kong Government : Hong Kong External Merchandise Trade CDROM Volume 10, 1996-2005 Annual Data, 2006

\section{税関別貿易統計を用いた国際海上貨物流動量の推計*}

国際海上貨物流動統計は、社会資本整備計画の立案や物流業者の経営戦略の検討に有効である。アジア地 域においては、包括的な統計システムを管理する組織が存在しないことから、現在の所、総合的な国際海上 貨物流動統計は構築されていない。本研究では、税関別の貿易統計を使用して、港湾別のコンテナ貨物量を 推計する手法を示し、日本、中国、韓国間を対象として、推計手法の適用を行った。3力国の既存統計の特 性分析と、その統計值と推計值を比較し、推計手法の妥当性の検討を行った結果、推計手法の有効性を示し た。

\section{Estimation Method for International Seaborne Freight Flows Using Trade Statistics by Customs*}

By Hiroyuki KOSAKA**

Statistics on maritime freight flows are necessary for the effective planning of ports and for the analysis of ship scheduling. In Asia, however, there are no organizations that compile comprehensive statistical data on maritime freight flows. This study proposes a method to estimate maritime freight flows on a port-to-country basis. This estimation method is based on each custom's trade statistics. The author calculated maritime freight flows for Japan, Korea and China by applying this estimation method, and validated the estimation method by comparing the results of estimations and existing statistics. 